Article

\title{
New Haloterpenes from the Marine Red Alga Laurencia papillosa: Structure Elucidation and Biological Activity
}

\author{
Mohamed Shaaban ${ }^{1,2, *}$, Ghada S. E. Abou-El-Wafa ${ }^{3}$, Christopher Golz ${ }^{2}$ and Hartmut Laatsch ${ }^{2, *}$ \\ 1 National Research Centre, Chemistry of Natural Compounds Department, Division of Pharmaceutical \\ Industries, El-Behoos St. 33, Dokki, Cairo 12622, Egypt \\ 2 Institute of Organic and Biomolecular Chemistry, University of Göttingen, Tammannstrasse 2, \\ D-37077 Göttingen, Germany; cgolz@gwdg.de \\ 3 Department of Botany, Faculty of Science, Mansoura University, Algomhuria st. 60, \\ El-Mansoura 35516, Egypt; ghadas@mans.edu.eg \\ * Correspondence: ms.attia@nrc.sci.eg (M.S.); hlaatsc@gwdg.de (H.L.); Tel.: +2-(0)1019644009 or \\ +202-2701728-1550 (M.S.); +49-(0)551-393211 (H.L.)
}

check for

updates

Citation: Shaaban, M.;

Abou-El-Wafa, G.S.E.; Golz, C.;

Laatsch, H. New Haloterpenes from the Marine Red Alga Laurencia papillosa: Structure Elucidation and Biological Activity. Mar. Drugs 2021, 19, 35. https://doi.org/10.3390/ md19010035

Received: 12 December 2020 Accepted: 9 January 2021 Published: 14 January 2021

Publisher's Note: MDPI stays neutral with regard to jurisdictional clai$\mathrm{ms}$ in published maps and institutional affiliations.

Copyright: (C) 2021 by the authors. Licensee MDPI, Basel, Switzerland. This article is an open access article distributed under the terms and conditions of the Creative Commons Attribution (CC BY) license (https:// creativecommons.org/licenses/by/ $4.0 /)$.

\begin{abstract}
Analysis of the air-dried marine red alga Laurencia papillosa, collected near Ras-Bakr at the Suez gulf (Red Sea) in Egypt delivered five new halogenated terpene derivatives: aplysiolic acid (1), 7-acetyl-aplysiol (2), aplysiol-7-one (3), 11,14-dihydroaplysia-5,11,14,15-tetrol (5a), and a new maneonene derivative 6 , named 5-epi-maneolactone. The chemical structures of these metabolites were characterized employing spectroscopic methods, and the relative and absolute configurations were determined by comparison of experimental and ab initio-calculated NMR, NOE, ECD, and ORD data, and by X-ray diffraction of $\mathbf{2}$ and $\mathbf{6}$. The antimicrobial activities of the crude extract and compounds 1-3, 5a and 6 were studied.
\end{abstract}

Keywords: marine red algae; Laurencia papillosa; haloterpenes; biological activity

\section{Introduction}

Among the red algae, the genus Laurencia is known to produce the largest number and diversity of secondary metabolites, making it the world's chemically most complex seaweed genus [1]. Furthermore, several Laurencia metabolites have exhibited noteworthy antibacterial [2-5] insecticidal [3,6], antifungal [7], and antiviral activity [8], in addition to their anti-inflammatory, antiproliferative, antifouling, antifeedant, cytotoxic, ichthyotoxic, and insecticidal properties [9]. Certain Laurencia species have shown to be an unprecedented source of halogenated secondary metabolites, predominantly sesquiterpenes [10], diterpenes [11], and $C_{15}$ non-terpenoids, including halogenated cyclic enyne ethers and related allenes [12-14]. An example is the halogenated diterpene aplysiadiol (4), which was obtained from the marine mollusk Aplysia kurodai [15] and a Malaysian Laurencia species, and exhibited potent antibacterial activities [16].

In the course of our research to isolate and investigate bioactive metabolites from Laurencia algae collected from the shallow waters of the Red Sea on Egyptian coasts, a series of four halogenated bioactive decalin derivatives was isolated, namely aplysiolic acid (1), 7-acetyl-aplysiol (2), aplysiol-7-one (3), 11,14-dihydroaplysia-5,11,14,15-tetrol (5a), and a further chloro compound 6 (Figure 1). We named the latter 5-epi-maneolactone (6), because of the similarity with the maneonenes, bioactive $C_{15}$ acetogenins from L. obtusa $[17,18]$. Additionally, thyrsiferol [19], 10-hydroxykahukuene B [20], cholesterol, hexadecanoic acid, thymine, and uracil were gained from the dichloromethane-methanol extract of L. papillosa. The chemical structures of these compounds were determined by extensive 1D and 2D NMR and ESI HR mass measurements. Their relative and absolute configurations were derived by $1 \mathrm{D}$ and $2 \mathrm{D}$ NMR measurements, from ab initio calculations of ECD, ORD, ${ }^{13} \mathrm{C}$ NMR data, by geometry-derived NOE predictions, and by X-ray diffraction in case of 2 and 
6. The antimicrobial activity of the crude extract and of the new compounds was studied using a set of diverse microorganisms.<smiles>C=C1CC[C@@H](Br)[C@]2(C)CC[C@H](C(=O)O)C[C@]12O</smiles>

1<smiles>C=C1CC[C@@H](Br)[C@]2(C)CC[C@H](/C(C)=C/C=C/C(C)(O)P)C[C@]12O</smiles>

4<smiles>C=C1CC[C@@H](Br)[C@]2(C)CC[C@H](C(C)=O)C[C@]12O</smiles><smiles>CC(O)(P)[C@@H](O)/C=C/[C@@H](O)[C@H]1CC[C@@]2(C)[C@@H](Br)CCC(=O)[C@@]2(O)C1</smiles>

$5 a$<smiles>C=C1CC[C@@H](Br)[C@]2(C)CCC(=O)C[C@]12O</smiles>

3

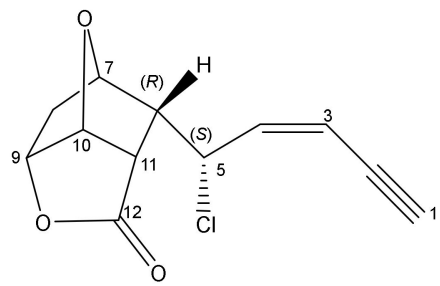

6

$\mathbf{5 b}=$ epimer of $\mathbf{5 a}$ in the side chain

Figure 1. Structures of new haloterpenes 1-3, 5a, 6 from L. papillosa.

\section{Results and Discussion}

\subsection{Working up and Structure Identification}

The dichloromethane-methanol extract of air-dried L. papillosa algae was fractionated by a series of chromatographic purification steps implying silica gel and size exclusion columns, to afford the haloterpenes 1-3, 5a-c, and 6 (Figure 1), and additionally thyrsiferol [19], 10-hydroxykahukuene B [20], cholesterol, hexadecanoic acid, thymine, and uracil. The physico-chemical properties of the new compounds are listed in Table 1.

Table 1. Physico-chemical properties of compounds 1-3a-c, 5a and 6.

\begin{tabular}{|c|c|c|c|c|c|}
\hline & Aplysiolic Acid (1) & 7-Acetyl-aplysiol (2) & Aplysiol-7-one (3) & $\begin{array}{c}\text { Dihydroaplysiatetrol } \\
\text { (5a) }\end{array}$ & $\begin{array}{c}\text { 5-epi-Maneolactone } \\
\text { (6) }\end{array}$ \\
\hline Appearance & colorless solid & colorless solid & colorless solid & colorless oil & colorless solid \\
\hline$R_{\mathrm{f}}$ & $0.26^{\mathrm{a}}$ & $0.28^{\mathrm{b}}$ & $0.39^{b}$ & $0.30^{\mathrm{a}}$ & $0.50^{\mathrm{b}}$ \\
\hline $\begin{array}{l}\text { Anisaldehyde/ } \\
\text { sulfuric acid }\end{array}$ & $\begin{array}{c}\text { pink, turning later to } \\
\text { violet }\end{array}$ & $\begin{array}{l}\text { pink, turning later to } \\
\text { violet }\end{array}$ & $\begin{array}{l}\text { pink, turning later to } \\
\text { violet }\end{array}$ & $\begin{array}{c}\text { pink, turning later to } \\
\text { violet }\end{array}$ & brownish gray \\
\hline Molecular formula & $\mathrm{C}_{13} \mathrm{H}_{19} \mathrm{BrO}_{3}$ & $\mathrm{C}_{14} \mathrm{H}_{21} \mathrm{BrO}_{2}$ & $\mathrm{C}_{12} \mathrm{H}_{17} \mathrm{BrO}_{2}$ & $\mathrm{C}_{20} \mathrm{H}_{33} \mathrm{BrO}_{4}$ & $\mathrm{C}_{12} \mathrm{H}_{11} \mathrm{ClO}_{3}$ \\
\hline $\begin{array}{l}(+)-\text { ESIMS: } \\
m / z(\%)\end{array}$ & & $\begin{array}{c}323 / 325[\mathrm{M}+\mathrm{Na}]^{+} \\
(100: 95.4) \\
623 / 625 / 627[2 \mathrm{M}+ \\
\mathrm{Na}]^{+},(10: 31: 10)\end{array}$ & $\begin{array}{c}296 / 298[\mathrm{M}+\mathrm{Na}]^{+} \\
(88: 100), 569[2 \mathrm{M}+ \\
\mathrm{Na}^{+}\end{array}$ & $\begin{array}{c}439 / 441[\mathrm{M}+\mathrm{Na}]^{+} \\
(100: 97), 855 / 857 / 859 \\
{[2 \mathrm{M}+\mathrm{Na}]^{+}} \\
(20: 57: 19)\end{array}$ & $\begin{array}{c}261 / 263[\mathrm{M}+\mathrm{Na}]^{+} \\
(100: 31), 499[2 \mathrm{M}+ \\
\mathrm{Na}]^{+}(4)\end{array}$ \\
\hline $\begin{array}{c}(-) \text {-ESIMS: } \\
m / z(\%)\end{array}$ & $\begin{array}{c}301 / 303[\mathrm{M}-\mathrm{H}]^{-} \\
(100: 90.5), \\
603 / 605 / 607[2 \mathrm{M}- \\
\mathrm{H}]^{-}(37: 57: 21)\end{array}$ & $\begin{array}{c}335 / 337 / 339[\mathrm{M}+ \\
\mathrm{Cl}]^{-}(69: 100: 25)\end{array}$ & & $\begin{array}{c}461 / 463[\mathrm{M}+2 \mathrm{Na}- \\
3 \mathrm{H}]^{-}(100: 97) \\
831 / 833 / 855[2 \mathrm{M}- \\
\mathrm{H}]^{-},(25: 52: 27)\end{array}$ & \\
\hline$(+)$-ESIHRMS: $(m / z)$ & & $\begin{array}{c}323.0615[\mathrm{M}+\mathrm{Na}]^{+} \\
\left(^{+} \text {calc. } 323.0617 \text { for }\right. \\
\left.\mathrm{C}_{14} \mathrm{H}_{21} \mathrm{BrNaO}_{2}\right) \\
625.1326[2 \mathrm{M}+\mathrm{Na}]^{+} \\
(\text {calc. } 625.1327 \text { for } \\
\left.\mathrm{C}_{28} \mathrm{H}_{42} \mathrm{Br}_{2} \mathrm{NaO}_{4}\right)\end{array}$ & & $\begin{array}{c}439.1454[\mathrm{M}+\mathrm{Na}]^{+} \\
\text {(calc. } 439.1454 \text { for } \\
\left.\mathrm{C}_{20} \mathrm{H}_{33} \mathrm{BrO}_{4} \mathrm{Na}\right)\end{array}$ & $\begin{array}{c}261.0299[\mathrm{M}+\mathrm{Na}]^{+} \\
\left(\text {calc. } 261.0289 \text { for }^{\left.\mathrm{C}_{12} \mathrm{H}_{11} \mathrm{ClO}_{3} \mathrm{Na}\right)}\right.\end{array}$ \\
\hline
\end{tabular}


Table 1. Cont.

\begin{tabular}{|c|c|c|c|c|c|}
\hline & Aplysiolic Acid (1) & 7-Acetyl-aplysiol (2) & Aplysiol-7-one (3) & $\begin{array}{c}\text { Dihydroaplysiatetrol } \\
(5 a)\end{array}$ & $\begin{array}{c}\text { 5-epi-Maneolactone } \\
\text { (6) }\end{array}$ \\
\hline$(-)$-ESIHRMS $(m / z)$ & $\begin{array}{c}301.0441[\mathrm{M}-\mathrm{H}]- \\
\text { (calc. } 301.0444 \text { for } \\
\mathrm{C}_{13} \mathrm{H}_{18} \mathrm{BrO}_{3} \text { ) }\end{array}$ & $\begin{array}{c}335.0418[\mathrm{M}+\mathrm{H}]^{-} \\
\text {(calc. } 335.0418 \text { for } \\
\mathrm{C}_{14} \mathrm{H}_{21} \mathrm{BrClO}_{2} \text { ) }\end{array}$ & & & \\
\hline $\mathrm{IR}(\mathrm{KBr}) v \mathrm{~cm}^{-1}$ & & & & & $\begin{array}{c}3259,2361,2182,1782, \\
1592,1358,1160,1018, \\
895,841,794,665\end{array}$ \\
\hline$[\alpha]^{20}{ }_{\mathrm{D}}(\mathrm{MeOH})$ & $-34.8(\mathrm{c}, 0.13)$ & $-55.4(\mathrm{c}, 0.24)$ & & $-31.9(\mathrm{c}, 0.12)$ & $-155.8(\mathrm{c}, 0.26)$ \\
\hline
\end{tabular}

${ }^{\mathrm{a}} \mathrm{CH}_{2} \mathrm{Cl}_{2} / 10 \% \mathrm{MeOH} ;{ }^{\mathrm{b}} \mathrm{CH}_{2} \mathrm{Cl}_{2} / 3 \% \mathrm{MeOH}$.

\subsubsection{Aplysiolic Acid}

Compound $\mathbf{1}$ was isolated as an optically active colorless solid, exhibiting neither UV-absorbance nor fluorescence on silica gel. On TLC, it was detected as a pink spot after spraying with anisaldehyde/sulfuric acid, tentatively pointing to a terpenoidal moiety. The (-)-ESI mass spectrum showed $[\mathrm{M}-\mathrm{H}]^{-}$ion signals of nearly equal intensities at $\mathrm{m} / \mathrm{z}$ 301 and 303 Dalton, and a triple ion-peak at $\mathrm{m} / \mathrm{z} 605[2 \mathrm{M}-\mathrm{H}]^{-}$, indicating the presence of one bromine atom. The (-)-ESI HR mass spectrum suggested the molecular formula $\mathrm{C}_{13} \mathrm{H}_{19} \mathrm{BrO}_{3}$, indicating four double bond equivalents (DBE) (Table 1).

The ${ }^{13} \mathrm{C}$ NMR spectrum (Table 2) showed a total of 13 resonances, amongst them ten in the aliphatic, two in the olefinic, and one in the carbonyl region. The ${ }^{1} \mathrm{H}$ NMR pattern exhibited two singlets at $\delta 4.90$ and 4.81, which were assigned by $\mathrm{H}, \mathrm{H}$ COSY and HMQC spectra as exo-methylene protons $\left(\delta_{\mathrm{C}} 110.2\right)$. The respective quaternary carbon signal appeared at $\delta 148.5$ and was assigned by HMBC correlations (Figure 2). The carbonyl group, together with one methyl, six methylene, and two methine groups and three fully substituted carbons, sums up to $\mathrm{C}_{13} \mathrm{H}_{17} \mathrm{BrO}$. Respectively, $\mathbf{1}$ should contain two rings, and the remaining two hydrogen and oxygen atoms are forming hydroxyl groups.

Table 2. ${ }^{13} \mathrm{C}(125 \mathrm{MHz})$ and ${ }^{1} \mathrm{H}(600 \mathrm{MHz}) \mathrm{NMR}$ data of aplysiolic acid (1) and related analogues 2, 3 in $\mathrm{CDCl}_{3}$.

\begin{tabular}{|c|c|c|c|c|c|c|}
\hline \multirow{2}{*}{ Nr. } & \multicolumn{2}{|r|}{1} & \multicolumn{2}{|r|}{2} & \multicolumn{2}{|r|}{3} \\
\hline & $\delta_{C}$ & $\delta_{\mathrm{H}}(J$ in $\mathrm{Hz})$ & $\delta_{C}$ & $\delta_{H}(J$ in $\mathrm{Hz})$ & $\delta_{C}$ & $\delta_{\mathrm{H}}(J$ in $\mathrm{Hz})$ \\
\hline 1 & 62.9 & $4.72(\mathrm{dd}, 12.4,4.7)$ & 63.2 & $4.69(\mathrm{dd}, 12.3,4.7)$ & 61.5 & $4.67(\mathrm{dd}, 12.7,4.5)$ \\
\hline 2 & 33.9 & $2.20(\mathrm{~m}), 2.13(\mathrm{~m})$ & 33.9 & $2.15(\mathrm{~m}), 2.08(\mathrm{~m})$ & 34.0 & $2.24(\mathrm{~m}), 2.09(\mathrm{~m})$ \\
\hline 3 & 32.5 & $\begin{array}{c}2.70(\mathrm{dddd}, 13.5,9.6 \\
5.7,2.1) 2.15(\mathrm{~m})\end{array}$ & 32.5 & $\begin{array}{l}2.11(\mathrm{~m}), 2.67(\mathrm{tdt} \\
13.0,5.6,2.0)\end{array}$ & 32.1 & $\begin{array}{c}2.64(\mathrm{ddd}, 13.6,5.0, \\
2.8), 2.17(\mathrm{ddd}, 13.6, \\
5.0,2.0)\end{array}$ \\
\hline 4 & 148.5 & & 148.6 & & 147.7 & \\
\hline 5 & 76.2 & & 76.3 & & 79.6 & \\
\hline 6 & 34.1 & $\begin{array}{c}2.04(\mathrm{dd}, 13.8,12.8) \\
1.83(\mathrm{~m})\end{array}$ & 33.1 & $\begin{array}{c}1.65(\mathrm{ddd}, 14.0,3.9 \\
1.3), 1.91(\mathrm{~m})\end{array}$ & 48.5 & $2.86(\mathrm{~d}, 14.6), 2.38(\mathrm{~m})$ \\
\hline 7 & 38.2 & $2.94(\mathrm{tt}, 12.9,4.1)$ & 46.3 & $2.90(\mathrm{tt}, 12.7,4.0)$ & 209.9 & \\
\hline 8 & 23.5 & $1.90(\mathrm{~m}), 1.66(\mathrm{~m})$ & 23.4 & $1.80(\mathrm{~m}), 1.45(\mathrm{~m})$ & 37.5 & $2.41(\mathrm{~m})$ \\
\hline 9 & 32.0 & $1.77(\mathrm{~m})$ & 32.2 & $1.74(\mathrm{~m})$ & 33.3 & $2.08(\mathrm{~m})$ \\
\hline 10 & 43.0 & & 43.0 & & 43.4 & \\
\hline 11 & 181.0 & & 211.8 & & 110.9 & $\begin{array}{c}4.94(\mathrm{~d}, 2.0), 4.74(\mathrm{~d}, \\
1.5)\end{array}$ \\
\hline 12 & 14.8 & $0.96(\mathrm{~s})$ & 14.7 & $0.89(\mathrm{~s})$ & 14.8 & $1.18(\mathrm{~s})$ \\
\hline 13 & 110.2 & $\begin{array}{c}4.90(\mathrm{dd}, 2.0,1.0), 4.81 \\
(\mathrm{~d}, 1.5)\end{array}$ & 110.0 & $4.86(\mathrm{~m}), 4.79(\mathrm{t}, 1.3)$ & & \\
\hline 14 & - & & 28.3 & $2.13(\mathrm{~s})$ & & \\
\hline
\end{tabular}

"-" means that there is no carbon and therefore also no shift, as seen in the structure. An alternative is just to omit the hyphen. 


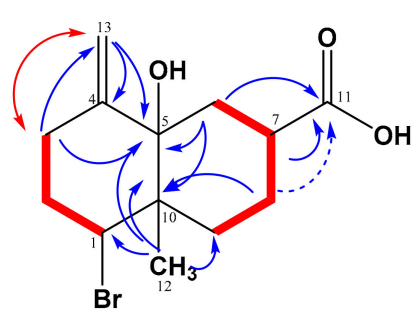

1

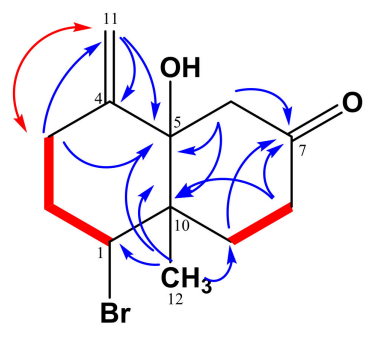

3

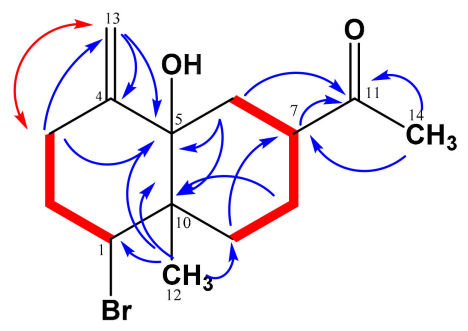

2

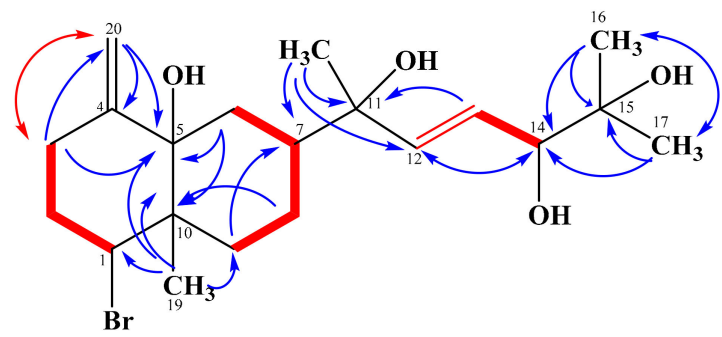

$5 a$

Figure 2. $\mathrm{H}, \mathrm{H} \operatorname{COSY}\left({ }^{3} J \simeq,{ }^{4} J\right)$ and $\operatorname{HMBC}(\frown, \curvearrowleft)$ correlations of $\mathbf{1}-\mathbf{3}, \mathbf{5 a}$.

Based on the $\mathrm{H}, \mathrm{H}$ COSY correlations, two fragments were identified in 1, a 1,1,3trisubstituted propane (- $\left.\mathrm{CH}_{2}-\mathrm{CH}_{2}-\mathrm{CH}-\right)$, and a 1,2,4-trisubstituted butane $\left(-\mathrm{CH}_{2}-\mathrm{CH}-\mathrm{CH}_{2}-\right.$ $\left.\mathrm{CH}_{2}-\right)$ unit, respectively. The terminal methylene protons in the first fragment $(\delta 2.70,2.15)$ showed ${ }^{2} J$ and ${ }^{3} J$ HMBC correlations with the olefinic carbons C-4 and C- 13 , confirming their direct neighborhood. One of these methylene protons $(\delta 2.70)$ showed a ${ }^{4} J$ COSY signal with the exo-methylene protons. The methine proton $\mathrm{H}-1(\delta 4.72)$ exhibited ${ }^{2} J$ and ${ }^{3} J$ correlations towards $C-10(\delta 43.0)$ and the methyl singlet of C-12 $(\delta 14.8)$, respectively, suggesting a connection of C-10 with C-1 and Me-12. If C-5 is hydroxylated ( $\delta 76.2)$, the downfield shift of $\mathrm{C}-1(\delta 62.9)$ fits best on its substitution with bromine [21]. Among others, the methylene group $\mathrm{CH}_{2}-3$ showed a ${ }^{3} \mathrm{HMBC}$ correlation towards $\mathrm{C}-5$, which itself gave cross signals with the methylene protons $\mathrm{H}_{2}-13$ and Me-12, so that an exomethylenecyclohexane (ring A) was formed.

Further HMBC and NOESY correlations (Figures 2 and 3 ) indicated that the butanediyl fragment formed a second cyclohexane (ring B) via C-10 ( $\delta 43.0)$ and C-5 ( $\delta 76.2) . \mathrm{CH}_{2}-9$ correlated with C-10 and Me-12 and showed all other expected HMBC and NOESY correlations. In a similar way, the ring closure between $\mathrm{CH}_{2}-6$ and $\mathrm{C}-5$ was confirmed. According to ${ }^{2} J$ and ${ }^{3} J$ HMBC correlations from $\mathrm{H}_{\mathrm{ax}, \beta}-6(\delta 2.04), \mathrm{H}_{\alpha}-7(\delta 2.94)$, and $\mathrm{H}_{\mathrm{ax}, \beta}-8(\delta 1.66$, weak) with $C-11(\delta 181.0)$, the missing atoms are forming a carboxyl group at $C-7$.

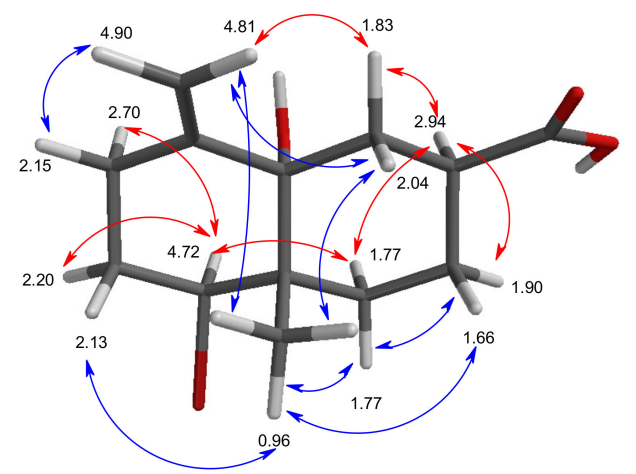

Figure 3. NOESY correlations $(\curvearrowleft=$ front side, $\beta$-orientation, $\cdots$ = weak); $\square$ =backside, $\alpha$-orientation;) of all-(S)-aplysiolic acid (1); proton shifts = values at the atoms. For atom distances, see Table S1. 
Due to the low flexibility of $\mathbf{1}$, its NOESY signals were surprisingly clear and easy to interpret. Me-12 showed correlations with $\mathrm{H}_{\mathrm{ax}, \beta}-2, \mathrm{H}_{\mathrm{ax}, \beta}-6, \mathrm{H}_{\mathrm{ax}, \beta}-8$, and $\mathrm{H}_{\mathrm{eq}, \beta}-9$ but not with $\mathrm{H}-1, \mathrm{H}_{\alpha}-2, \mathrm{H}_{\alpha}-6, \mathrm{H}_{\alpha}-7$, and $\mathrm{H}_{\alpha}-8$, so that all correlating protons should be in a syn-facial position with the methyl group. The NOE between $\mathrm{H}-7$ and $\mathrm{H}_{\mathrm{eq}, \alpha}-6$, $\mathrm{H}_{\mathrm{eq}, \alpha}-8, \mathrm{H}_{\mathrm{ax}, \alpha}-9$, and of $\mathrm{H}-1$ with $\mathrm{H}_{\mathrm{eq}, \alpha}-2, \mathrm{H}_{\mathrm{ax}, \alpha}-3, \mathrm{H}_{\mathrm{ax}, \alpha}-9$, but not with Me-12, indicated their anti-position with respect to Me-12, resulting in the rel-(1S,7S,10S)-configuration. DFT-calculations of the 1-geometry showed that the strong NOE effect between ( $\mathrm{Z})-\mathrm{H}$ $13(\delta 4.81)$ and $\mathrm{H}_{2}-6(\delta 2.04,1.83)$, and between $\mathrm{H}_{\beta}-6(2.04)$ and Me-12 (0.96) is not explainable by a cis-decalin, but requires definitely a trans-decalin with a rel- $(5 S, 10 S)$ configuration (see Figures S2 and S3). As the sign of the ORD data calculated for all-(S)-1 agreed with the experimental data, the decalin was elucidated as 5-bromo-8a-hydroxy4a-methyl-8-methylene-decahydronaphthalene-2-carboxylic acid (1), having the absolute all-(S)-configuration. We named it aplysiolic acid, with respect to the similarity with aplysiadiol (4) [15]. For aplysiadiol (4) and anhydroaplysiadiol [21], the same relative configuration as for $\mathbf{1}$ was published, and we confirmed their absolute configuration by agreement of calculated and published negative sign of their optical rotation as all-(S) as well (Table S4).

\subsubsection{7-Acetyl-aplysiol}

An additional optically active colorless solid had similar chromatographic properties as 1, but with noticeably less polarity. The ESI HR mass spectrum indicated the molecular formula $\mathrm{C}_{14} \mathrm{H}_{21} \mathrm{BrO}_{2}$ with four double bond equivalents (DBE) as well. However, an $\mathrm{OH}$ group in 1 was formally exchanged against a methyl group. Respectively, a methyl singlet $\left(\delta_{\mathrm{H}} 2.13\right)$ and its corresponding carbon (28.3) were visible. The carboxyl signal in 1 (181.0) was exchanged in 2 against a keto carbonyl at $\delta_{C} 211.8$, but the remaining ${ }^{1} \mathrm{H}$ and ${ }^{13} \mathrm{C}$ NMR signals were very similar in both compounds. On the basis of long-range 2D NMR couplings (Figure 2) and NOESY experiments (Figure 4), the structure was assigned as 2, which we named 7-acetyl-aplysiol. From this ketone, the acid $\mathbf{1}$ may be formed in a haloform reaction (Einhorn reaction). With respect to the negative optical rotation, the decalin system of $\mathbf{2}$ should have the same absolute all-(S)-configuration as $\mathbf{1}$, which also agrees with biosynthetic considerations. However, as some doubt remained after comparison of the calculated and experimental ECD spectra, a crystal of $\mathbf{2}$ was analyzed additionally by $\mathrm{X}$-ray diffraction (Figure $\mathrm{S6}$ ), which reassured the all-(S)-configuration.

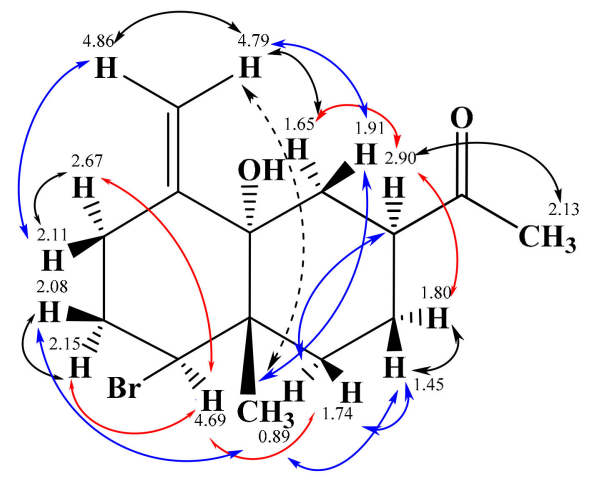

2

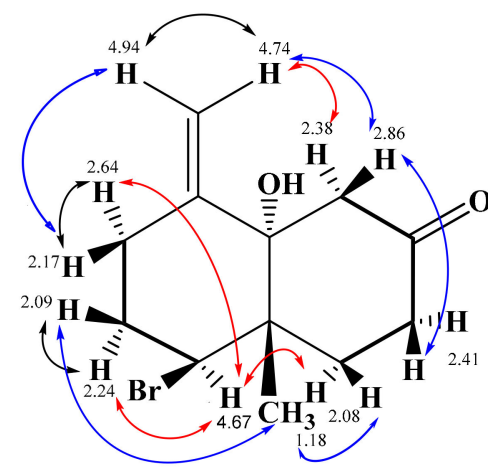

3

Figure 4. Main NOESY correlations $(\curvearrowleft=$ front side, $\beta$-orientation $\cdots$ = weak; $\curvearrowleft$ = backside, $\alpha$-orientation; $\multimap$ geminal correlations) of all-(S)-7-acetyl-aplysiol (2) and all-(S)-aplysiol-7-one (3).

\subsubsection{Aplysiol-7-one}

A third closely related decalin gave the molecular formula $\mathrm{C}_{12} \mathrm{H}_{17} \mathrm{BrO}_{2}$ by ESI $\mathrm{HR}$, containing $4 \mathrm{DBE}$ as well. The ${ }^{1} \mathrm{H}$ and ${ }^{13} \mathrm{C}$ NMR spectra of 3 resembled those of $\mathbf{1}$ and 2; however, the signals of $\mathrm{CH}-7$ (in 1 and 2) and $\mathrm{CH}_{3}-14$ (in 2) were absent, and the $\mathrm{ABX}$ signal of $\mathrm{CH}_{2}-6$ in $\mathbf{1}$ and $\mathbf{2}$ had changed into an $\mathrm{AB}$ signal. As indicated by the HMBC 
correlations and the downfield shifts of $\mathrm{CH}_{2}-6$ and $\mathrm{CH}_{2}-8$, the carbonyl signal at $\delta_{\mathrm{C}} 209.0$ was due to a $B$-decalone. Furthermore, long-range 2D NMR couplings (Figure 2) confirmed structure 3, which we named as aplysiol-7-one. In addition, the all-(S)-configuration was plausible for NOESY experiments (Figure 4) and biosynthetic reasons; it was, however, not further analyzed due to an inseparable contamination by 10-hydroxykahukuene B [20].

\subsubsection{1,14-Dihydroaplysia-5,11,14,15-tetrols}

A further brominated terpenoide with moderate polarity was isolated as an optically active resin with color reactions similar as of $\mathbf{1}$ (Table 1). The NMR spectrum (Table 3) of this compound showed $20{ }^{13} \mathrm{C}$ signals. At high magnification, however, each of them appeared as a group of up to four signals in distances of $<0.2 \mathrm{ppm}$ (Figures S34 and S35), so that a mixture of four stereoisomers or otherwise closely related compounds was expected; this was confirmed by the ${ }^{1} \mathrm{H}$ NMR signal of the $\Delta^{12}$ double bond (Figure S11) and also by analytical HPLC analyses, where three components in the ratio of $~ 1: 1: 1$ were separated. By HPLC/HRMS, two stereoisomers $\mathrm{C}_{20} \mathrm{H}_{33} \mathrm{BrO}_{4}(\mathbf{5 a}, \mathbf{b})$ and a slightly more polar component $\mathrm{C}_{20} \mathrm{H}_{33} \mathrm{BrO}_{5}$ (5c) were detected (Figures $\mathrm{S} 12$ and $\mathrm{S} 13$ ). The latter compound seems to be a 11,14-dihydroaplysiapentol; we need, however, to isolate further material to fully elucidate the structure (see Supporting Information).

Table $3 .{ }^{13} \mathrm{C}(125 \mathrm{MHz})$ and ${ }^{1} \mathrm{H}$ NMR $(300 \mathrm{MHz})$ data of dihydroaplysiatetrols (5a and $\left.5 \mathbf{b}\right)$ in $\mathrm{CD}_{3} \mathrm{OD}$. For the ${ }^{13} \mathrm{C}$ shifts, we used two digits behind the decimal point to differentiate between $\mathbf{5 a}$ and its epimer $\mathbf{5} \mathbf{b}$ ); in Figure S15, the average of shifts for $\mathbf{5} \mathbf{a}$ and $\mathbf{5} \mathbf{b}$ was used with only one digit.

\begin{tabular}{ccccc}
\hline \multirow{2}{*}{$\mathbf{N r}}$. & \multicolumn{2}{c}{$\mathbf{5 a}$} & \multicolumn{2}{c}{ Epimer $\mathbf{5 b}$} \\
\cline { 2 - 5 } & \multicolumn{1}{c}{$\boldsymbol{\delta}_{\mathbf{C}}$} & $\boldsymbol{\delta}_{\mathbf{H}}(\boldsymbol{J} \mathbf{~ i n ~} \mathbf{H z})$ & $\boldsymbol{\delta}_{\mathbf{C}}$ & $\boldsymbol{\delta}_{\mathbf{H}}(\boldsymbol{J} \mathbf{~ i n ~} \mathbf{H z})$ \\
\hline 1 & 65.23 & $4.72(\mathrm{~m})$ & 65.23 & $4.72(\mathrm{~m})$ \\
2 & 35.61 & $2.14(\mathrm{~m}), 2.10(\mathrm{~m})$ & 35.61 & $2.13(\mathrm{~m}), 2.08(\mathrm{~m})$ \\
3 & 33.69 & $2.77(\mathrm{~m}), 2.12(\mathrm{~m})$ & 33.69 & $2.77(\mathrm{~m}), 2.09(\mathrm{~m})$ \\
4 & 151.64 & & 151.61 & \\
5 & 77.28 & & 77.27 & \\
6 & 32.75 & $1.66(\mathrm{~m}), 1.75(\mathrm{~m})$ & 32.75 & $1.66(\mathrm{~m}), 1.73$ \\
7 & 43.48 & $1.95(\mathrm{~m})$ & 43.65 & $1.95(\mathrm{~m})$ \\
8 & 22.22 & $1.33,1.67(\mathrm{~m})$ & 22.93 & $1.33,1.60(\mathrm{~m})$ \\
9 & 34.03 & $1.68(\mathrm{~m})$ & 33.96 & $1.67(\mathrm{~m})$ \\
10 & 44.17 & & 44.17 & \\
11 & 75.39 & & 75.38 & $5.77(\mathrm{~d}, 15.6)$ \\
12 & 139.83 & $5.79(\mathrm{~d}, 16.3)$ & 140.46 & $5.71(\mathrm{dd}, 15-16$, \\
13 & 128.08 & $5.74(\mathrm{dd}, 15-16$, & 127.95 & $6-7)$ \\
14 & & $6-7)$ & & $3.86(\mathrm{~m})$ \\
15 & 80.33 & $3.85(\mathrm{~m})$ & 80.39 & $1.15(\mathrm{~s})$ \\
16 & 73.69 & & 73.66 & $1.16(\mathrm{~s})$ \\
17 & 25.97 & $1.15(\mathrm{~s})$ & 26.07 & $1.27(\mathrm{~s})$ \\
18 & 25.11 & $1.15(\mathrm{~s})$ & 25.16 & $0.891(\mathrm{~s})$ \\
19 & 26.30 & $1.27(\mathrm{~s})$ & 26.22 & $4.83(\mathrm{~s}), 4.75(\mathrm{~s})$ \\
20 & 15.21 & $0.89(\mathrm{~s})$ & 15.21 & \\
\hline & 109.15 & $4.84(\mathrm{~s}), 4.74(\mathrm{~s})$ & 109.17 & \\
\hline
\end{tabular}

Both molecular formulas indicated four DBE (Table 1), and the COSY, HSQC, HMBC (Figure 2), and NOESY (Figure S15) data confirmed the same brominated rel-(1S,5S,7S,10S)exomethylene-decalin skeleton as in 1-3. However, instead of the carboxy or the acetyl group, respectively, a 6-methyl-hept-3-ene-2,5,6-triol-2-yl side chain was found: the singlet of Me-18 $\left(\delta_{\mathrm{H}} 1.27\right)$ displayed HMBC correlations with C-7, C-11 $\left(\delta_{\mathrm{C}} 75.4\right)$, and the olefinic carbon $\mathrm{C}-12\left(\delta_{C} 139.8\right)$. Further COSY and HMBC correlations completed the chain from $\mathrm{CH}-7$ to Me-16/Me-17. Accordingly, structures $5 \mathbf{a} / \mathbf{b}$ were elucidated as further new aplysiadiol derivatives [15] and named, respectively, as 11,14-dihydroaplysia-5,11,14,15-tetrols. Also here, the same absolute configuration as in 1-3 was assumed for the decalin system for biosynthetic reasons, so that only the stereochemistry of the side chain remained open. 
On this basis, the absolute configuration of the main component $\mathbf{5 a}$ was determined as $(1 S, 5 S, 7 S, 10 S, 11 R, 14 R)$ by correlation of NOE signals with ab-initio calculated atom distances (Table S6 and Figure S7); the other diastereomers could not be assigned, due to overlapping signals.

Aplysiadiol derivatives are biosynthetically regarded as extended sesquiterpenes; they represent examples of the rare prenylated eudesmane type, which commonly occur in terrestrial plants [22]. A few compounds of this type have been isolated from marine mollusks [15], brown algae [23], and soft corals [24-26].

\subsubsection{5-epi-Maneolactone}

Compound 6 displayed neither UV absorbance nor fluorescence on TLC, but turned brownish gray with anisaldehyde/sulfuric acid on heating. The molecular weight was determined by ESI MS: two quasi-molecular ion peaks in the ratio of 1:0.33 at $\mathrm{m} / \mathrm{z} 238$ and 240 indicated the presence of one chlorine atom. The corresponding molecular formula $\mathrm{C}_{12} \mathrm{H}_{11} \mathrm{ClO}_{3}$ was determined by ESI HRMS and indicated seven DBE (Table 1). The IR spectrum of 6 displayed a characteristic vibration signal $\left(v=2361 \mathrm{~cm}^{-1}\right)$ of an acetylenic bond. Two absorption bands at $v=1781$ and $1592 \mathrm{~cm}^{-1}$ indicated the presence of a lactone carbonyl and an olefinic double bond, respectively, so that three rings were expected.

The ${ }^{1} \mathrm{H}$ NMR methine signal at $\delta_{\mathrm{H}} 3.36$ did not show an HSQC correlation; however, a large $\mathrm{HMBC}$ coupling with the $\mathrm{CH}$ carbon at $\delta_{\mathrm{C}} 86.5$ and a smaller one with a $\mathrm{C}_{\mathrm{q}}$ at $\delta_{C} 78.2$ was noted. Together with strong long-range correlations with a cis-double bond $\left(\delta_{C} 113.8,139.2, J=10.5 \mathrm{~Hz}\right)$, this indicated a terminal acetylene in conjugation with a double bond. According to further HMBC and COSY correlations, the (Z)-enyne unit was connected with the methines $\mathrm{C}-5$ and $\mathrm{C}-6$, and the latter additionally with $\mathrm{CH}-7$ and $\mathrm{CH}-11$ (Figure 5). A detailed analysis resulted in a ((Z)-pent-2-en-4-ynyl)-cyclohexane, where the shift assignments of positions $\mathrm{CH}-7,-9$, and -10 remained open due to their overlapping ${ }^{1}$ H NMR signals (Table 4).

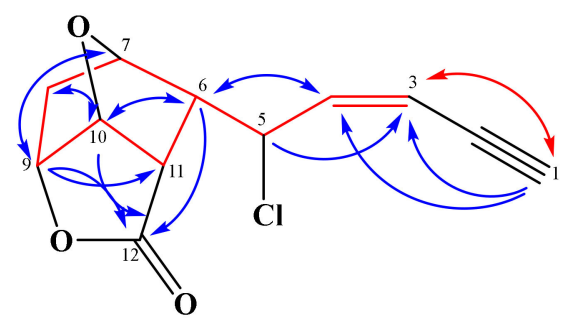

a

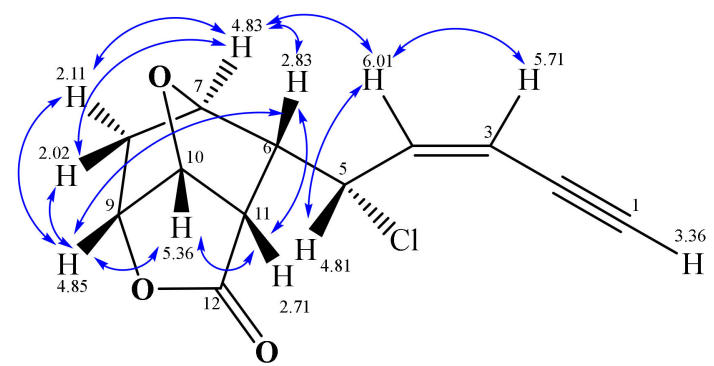

b

Figure 5. (a) H,H COSY (— connectivities $(\neg$ ) of 5-epi-maneolactone $(6$, right).

Table 4. ${ }^{13} \mathrm{C}(125 \mathrm{MHz})$ and ${ }^{1} \mathrm{H}$ NMR (300 MHz) data of 5-epi-maneolactone (6) in $\mathrm{CDCl}_{3}$.

\begin{tabular}{ccc}
\hline Nr. & $\boldsymbol{\delta}_{\mathbf{C}}$ & $\boldsymbol{\delta}_{\mathbf{H}}(\boldsymbol{J}$ in $\mathbf{H z})$ \\
\hline 1 & 86.5 & $3.36(\mathrm{dd}, 2.4,1.0)$ \\
2 & 78.2 & \\
3 & 113.8 & $5.71(\mathrm{ddd}, 10.5,2.5,0.5)$ \\
4 & 139.2 & $6.01(\mathrm{ddd}, 10.5,9.5,1.1)$ \\
5 & 55.3 & $4.81(\mathrm{~m})$ \\
6 & 52.9 & $2.83(\mathrm{dddd}, 12.1,10.4,4.1,1.7)$ \\
7 & 80.0 & $4.83(\mathrm{~m})$ \\
8 & 33.9 & $2.11(\mathrm{~d}, 18.0), 2.02(\mathrm{~m})$ \\
9 & 78.9 & $4.85(\mathrm{~m})$ \\
10 & 84.1 & $5.36(\mathrm{td}, 5.0,0.9)$ \\
11 & 42.9 & $2.71(\mathrm{ddd}, 10.2,5.1,0.8)$ \\
12 & 173.5 & \\
\hline
\end{tabular}


According to AntiBase [27], only two groups of metabolites with these structural features have been described before, the lembynes [2,28], and the maneonenes [17,18]. All were isolated from Laurencia spp. If chlorine was present, it was found in position C-5; also the shifts of 6 were explained best by chlorine at C-5. HMBC correlations of the upfield methine protons $\mathrm{CH}-6$ and $\mathrm{CH}-11$ with the signal at $\delta_{\mathrm{C}} 173.5$ connected the ester carbonyl C-12 with C-11, and the correlation with the oxymethine $\mathrm{CH}-9$ (or CH-7) via oxygen closed a lactone ring with $\mathrm{C}-12$. The remaining oxygen atom bridges the oxymethine groups $\mathrm{CH}-10$ with $\mathrm{CH}-7$ or $\mathrm{CH}-9$, so that all DBE were used. Further correlation analyses by means of COCON [29] delivered four structure options, with structure 6 being the only plausible one (Figure 5 and Figure S16). A suitable crystal allowed us finally to confirm this structure including the absolute configuration unambiguously by $\mathrm{X}$-ray diffraction (Figure 6). DFT calculations afforded the same absolute configuration, so that the validity of the computational methods applied here were additionally confirmed (see Supporting Information). We named compound $\mathbf{6}$ as 5-epi-maneolactone, as it looks like an oxidative cleavage product of the cis-maneonenes. It should be mentioned, however, that C-5 is $(R)$-configured in these compounds, oppositely to the (5S)-configured 6.

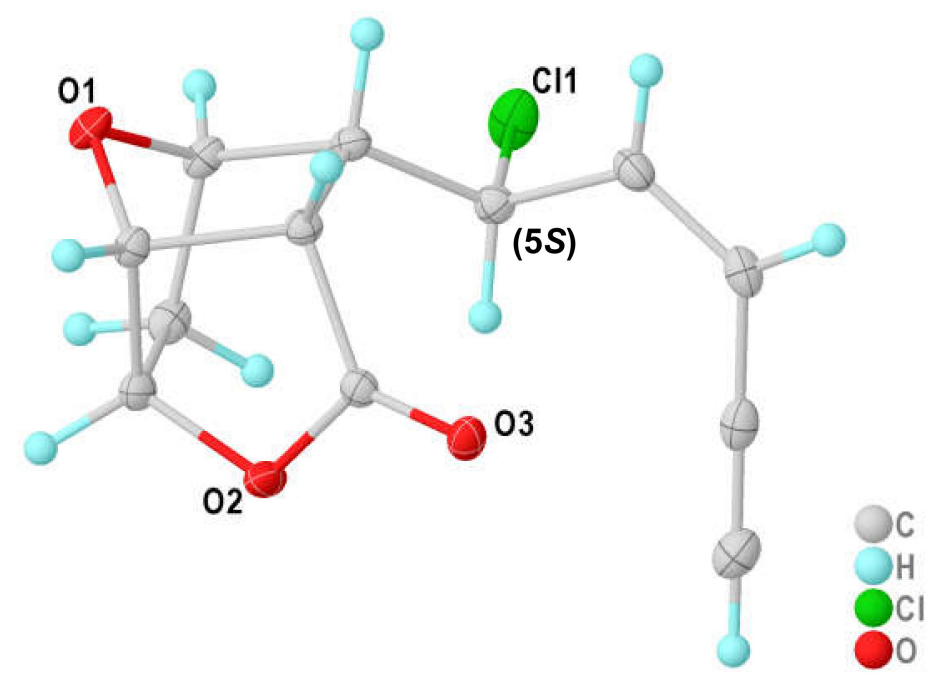

Figure 6. Crystal structure and absolute configuration of 5-epi-maneolactone (6) by X-ray diffraction.

\subsection{Biological Activities}

Antimicrobial activity testing of the crude extract of the red alga L. papillosa was carried out against ten microorganisms using the agar diffusion technique with paper platelets: Bacillus subtilis ATCC6051, Staphylococcus aureus, Streptomyces viridochromogenes Tü 57, Streptococcus pyogenes, Escherichia coli, Shigella sp., Proteus sp., Candida albicans, Mucor miehei Tü 284, and Chlorella vulgaris. The crude extract showed at $400 \mu \mathrm{g} / \mathrm{disk}$ a strong antibacterial activity against the Gram-positive Streptomyces viridochromogenes Tü 57 (30 mm). Among the tested compounds 1-3, 5, and 6, aplysiolic acid (1) and aplysiol-7-one (3) were only moderately active against $S$. aureus $(10.5 \mathrm{~mm})$ at a concentration of $40 \mu \mathrm{g} / \mathrm{disk}$.

\section{Materials and Methods}

\subsection{General Procedures}

IR spectra: FT/IR-4100 Infrared Spectrometer (Jasco, Inc., Easton, MD, USA). NMR spectra were measured with Varian Unity 300 and Varian Inova 600 spectrometers (Varian, Palo Alto, CA, USA). Optical rotations: Polarimeter (Perkin-Elmer, model 343, PerkinElmer Life and Analytical Sciences, Shelton, CT, USA). Electron spray ionization mass spectrometry (ESI MS): Finnigan LCQ ion trap mass spectrometer coupled with a Flux Instruments (Basel, Switzerland) quaternary pump Rheos 4000 and an HP 1100 HPLC (Nucleosil column EC 125/2, 100-5, C 18) with autosampler (Jasco 851-AS, Jasco, Inc., Easton, MD, USA) and a diode array detector (Finnigan Surveyor LC System, San Jose, CA, 
USA). High-resolution mass spectra (HRMS) were recorded by ESI MS on a MicrOTOF mass spectrometer (Bruker Daltonics, Billerica, MA, USA) or a LTQ Orbitrap XL (Thermo Fisher Scientific wissenschaftliche Geräte GmbH, 20354-Hamburg, Germany), equipped with an HPLC instrument (Thermo Scientific Accela HPLC System Markham, Ontario, Canada); for further details, see mass spectra in Supporting Information, e.g., Figures S12 and S17. Rf values are listed in Table 1 and were determined on Polygram SIL G/UV254 (Macherey \& Nagel, Düren, Germany). Size exclusion chromatography was performed on Sephadex LH-20 (Lipophilic Sephadex; Amersham Biosciences, Ltd., purchased from Sigma-Aldrich Chemie, Steinheim, Germany).

\subsection{Collection and Taxonomy of the Marine Alga}

The red alga L. papillosa (Forsk., Grev) was collected in summer 2009 at Ras Abu-Bakr, $65 \mathrm{~km}$ north of Ras Gharib on the Suez-Gulf, Red Sea, Egypt. The identification was carried out by G. S. Abou-El Wafa according to Nasr's method [30,31]. A reference specimen of the alga is kept at the Department of Botany, Faculty of Science, Mansoura University, Egypt. Samples of L. papillosa were separated from epiphytes and the algal material rinsed in tap water and distilled water. The sample was then spread on string nets, allowed to dry in air, ground, and stored in closed bottles at room temperature.

\subsection{Extraction and Isolation of the Bioactive Constituents}

The air-dried algal sample ( $850 \mathrm{~g})$ was extracted at room temperature with dichloromethane/methanol (1:1, $48 \mathrm{~h}$ for each batch). The extract was concentrated under reduced pressure to gain $8.83 \mathrm{~g}$ of residue, which was applied to column chromatography on silica gel (SC) using a gradient elution starting first with cyclohexane, then cyclohexane$\mathrm{CH}_{2} \mathrm{Cl}_{2}$ and finally with $\mathrm{CH}_{2} \mathrm{Cl}_{2}-\mathrm{MeOH}$. By TLC monitoring (UV light 254 and $366 \mathrm{~nm}$, Merck, 64579 Gernsheim, Germany) and by using anisaldehyde/sulfuric acid spray reagent, five fractions were obtained: I (1.73 g), II (0.32 g), III (0.73 g), IV (1.86 g), and V (1.92 g). Further SC (silica gel, cyclohexane- $\mathrm{CH}_{2} \mathrm{Cl}_{2}$ ) of fraction I afforded cholesterol $(46 \mathrm{mg}$ ) and hexadecanoic acid $(66.7 \mathrm{mg})$ as colorless solids. Purification of fraction II (SC on silica gel eluted with a cyclohexane/DCM/MeOH gradient and subsequently Sephadex $\mathrm{LH} 20\left(\mathrm{CH}_{2} \mathrm{Cl}_{2} / 40 \%\right.$ $\mathrm{MeOH})$ afforded compound 5 as a pale-yellow oil $(165 \mathrm{mg})$ and $\mathbf{6}$ as a colorless solid $(6 \mathrm{mg})$, respectively. $\mathrm{SC}$ of fraction IV on silica gel with a $\mathrm{DCM} / \mathrm{MeOH}$ gradient and subsequently Sephadex LH20 $\left.\left(\mathrm{CH}_{2} \mathrm{Cl}_{2} / 40 \% \mathrm{MeOH}\right)\right)$ resulted in 7-acetyl-aplysiol $(2,19.4 \mathrm{mg})$, aplysiol-7one $(3,4.8 \mathrm{mg})$ and 10-hydroxykahukuene $\mathrm{B}(5 \mathrm{mg})$ as colorless solids. SC of fraction V on silica gel $\left(\mathrm{CH}_{2} \mathrm{Cl}_{2} / \mathrm{MeOH}\right)$, followed by PTLC (DCM/10\% MeOH) and Sephadex LH20 $(\mathrm{MeOH})$ delivered aplysiolic acid $(\mathbf{1}, 1.4 \mathrm{mg})$, thyrsiferol $(1.5 \mathrm{mg})$, uracil $(1 \mathrm{mg})$, and thymine $(1 \mathrm{mg})$ as colorless solids. Detailed 2D NMR correlations (H,H COSY and HMBC) of compounds 1-3, $5 \mathbf{a}$ and $\mathbf{6}$ have been given in the Supplementary Data file, Figures S5-S55.

\subsection{Antimicrobial Assay}

Antimicrobial assays using the agar diffusion test [32] were performed as described previously [33]. M. miehei Tü 284 and S. viridochromogenes Tü 57 were obtained from the collection of H. Zähner (University of Tübingen, Germany), and Chlorella vulgaris was provided by the Algal Collection Göttingen. B. subtilis ATCC 6051 was obtained from the American Type Culture Collection, while S. aureus, E. coli and C. albicans are clinical isolates from Göttingen hospitals. Strains are kept in the strain collection of H. Laatsch, Institute of Organic and Biomolecular Chemistry, Georg-August University, Göttingen, Germany.

\subsection{Ab Initio Calculations}

DFT calculations were performed as described previously [34].

\subsection{Crystal Structure Determination of 7-acetylaplysiol (2) and 5-epi-maneolactone (6)}

The structures of $\mathbf{2}$ and $\mathbf{6}$ were determined by single-crystal X-ray diffraction on two dual source equipped Bruker D8 Venture four-circle-diffractometer (Bruker AXS GmbH, 
Karlsruhe, Germany). 7-Acetylaplysiol (2), $\mathrm{C}_{14} \mathrm{H}_{21} \mathrm{BrO}_{2}$, was crystallized from methanol as yellow plates in the orthorhombic crystal system in the non-centrosymmetric cpase group $P 2_{1} 2_{1} 22_{1}$; 5-epi-maneolactone (6), $\mathrm{C}_{12} \mathrm{H}_{11} \mathrm{ClO}_{3}$, was crystallized from $\mathrm{CHCl}_{3} / 20 \% \mathrm{MeOH}$ as colorless blocks in the monoclinic crystal system in the non-centrosymmetric space group $P 2{ }_{1}$. Absolute configuration could be determined reliably for both compounds with Flack's parameter of 0.001(5) and -0.014(7) for 7-acetylaplysiol (2) and 5-epi-maneolactone (6), respectively. Full crystallographic information can be retrieved from the CIF file and the Supporting Information. CCDC 2041564 (2) and 2008525 (6) contain the supplementary crystallographic data for this paper. These data can be obtained free of charge from The Cambridge Crystallographic Data Centre via www.ccdc.cam.ac.uk/datarequest/cif. For further data, refer to the Supporting Information.

\section{Conclusions}

Six haloterpenes, namely aplysiolic acid (1), 7-acetyl-aplysiol (2), aplysiol-7-one (3), 11,14-dihydroaplysia-5,11,14,15-tetrol (5a), the epimer $\mathbf{5 b}$ and 5-epi-maneolactone (6), along with thyrsiferol, 10-hydroxykahukuene B, cholesterol, hexadecanoic acid, thymine, and uracil were isolated from the marine red alga L. papillosa. The chemical structures of the new metabolites were characterized by employing spectroscopic methods (1D, 2D NMR, and ESI HR mass measurements). The relative and absolute configurations of the new compounds were determined by ab initio calculations of ECD, ORD, and NMR data, and for $\mathbf{2}$ and $\mathbf{6}$, additionally by X-ray diffraction. In a set of microorganisms, the crude extract was strongly active against Streptomyces viridochromogenes Tü $57(30 \mathrm{~mm})$, whereas the activity of the pure metabolites was low.

Supplementary Materials: NMR spectra and other supplementary data associated with this article can be found in the online version at https:/ / www.mdpi.com/1660-3397/19/1/35/s1.

Author Contributions: Conceptualization, M.S., G.S.E.A.-E.-W. and H.L.; methodology, G.S.E.A.-E.-W. and M.S.; validation, M.S. and H.L.; formal analysis, M.S., H.L. and C.G.; investigation, M.S. and H.L.; resources, G.S.E.A.-E.-W.; data curation, M.S. and H.L.; writing-Original draft preparation, M.S. and H.L.; writing—Review and editing, M.S. and H.L.; visualization, M.S., C.G. and H.L.; supervision, M.S.; project administration, M.S.; funding acquisition, M.S.; All authors have read and agreed to the published version of the manuscript.

Funding: M. Shaaban thanks the German Academic Exchange Service (DAAD) for a short-term fellowship (2015-2016).

Institutional Review Board Statement: Not applicable.

Informed Consent Statement: Not applicable.

Data Availability Statement: Further data are available on request from the corresponding authors.

Acknowledgments: The authors are thankful to Dr. H. Frauendorf (http:/ zentrale-analytik.chemie. uni-goettingen.de/index.htm) and Dr. M. John (https://www.uni-goettingen.de/de/nmr-abteilung/ 18904.html) for the mass and NMR spectra, and to Prof. Dr. Manuel Alcarazo (IOBC, Göttingen, https://www.uni-goettingen.de/de/prof.+dr.+manuel+alcarazo/522472.html) for providing his X-ray facilities; the diffractometer was kindly made available by the German Research Foundation (DFG, registration number INST 186/1237-1). We thank F. Lissy for biological activity tests.

Conflicts of Interest: The authors declare no conflict of interest.

Author Contributions: In memoriam of Dietrich Laatsch, +20 May, 2020. 


\begin{abstract}
Abbreviations
COSY: Correlation Spectroscopy; DFT: Density Functional Theory (quantum-mechanical modeling method); ECD: Electronic Circular Dichroism; ESI HRMS ElectroSpray Ionization High Resolution Mass Spectrometry; HMBC spectrum: heteronuclear multiple bond correlation spectrum; HMQC spectrum: Heteronuclear Multiple Quantum Coherence spectrum; HPLC: High Pressure Liquid Chromatography; NMR: Nuclear Magnetic Resonance; NOE: Nuclear Overhauser Effect; NOESY: Nuclear Overhauser Enhancement Spectroscopy; ORD: Optical Rotation Dispersion; TLC: Thin Layer Chromatography.
\end{abstract}

\title{
References
}

1. Pereira, R.C.; Dagama, B.A.P.; Teixeira, V.L.; Yoneshigue-Valentin, Y. Ecological roles of natural products of the Brazilian red seaweed Laurencia obtusa. Braz. J. Biol. 2003, 63, 665-672. [CrossRef] [PubMed]

2. Vairappan, C.S.; Daitoh, M.; Suzuki, M.; Abe, T.; Masuda, M. Antibacterial halogenated metabolites from the Malaysian Laurencia species. Phytochemistry 2001, 58, 291-297. [CrossRef]

3. Vairappan, C.S.; Kawamoto, T.; Miwa, H.; Suzuki, M. Potent antibacterial activity of halogenated compounds against antibioticresistant bacteria. Planta Med. 2004, 70, 1087-1090. [CrossRef] [PubMed]

4. Manilal, A.; Sujith, S.; Selvin, J.; Kiran, G.S.; Shakir, C.; Gandhimathi, R.; Panikkar, M.V.N. Biopotentials of seaweeds collected from southwest coast of India. J. Mar. Sci. Technol. 2009, 17, 67-73.

5. Shanmughapriya, S.; Manilal, A.; Sujith, S.; Selvin, J.; Kiran, G.S.; Natarajaseenivasan, K. Antimicrobial activity of seaweeds extracts against multi-resistant pathogens. Ann. Microbiol. 2008, 58, 535-541. [CrossRef]

6. El Sayed, K.A.; Dunbar, D.C.; Perry, T.L.; Wilkins, S.P.; Hamann, M.T.; Greenplate, J.T.; Wideman, M.A. Marine natural products as prototype insecticidal agents. J. Agric. Food Chem. 1997, 45, 2735-2739. [CrossRef]

7. Koenig, G.M.; Wright, A.D. Sesquiterpene content of the antibacterial dichloromethane extract of the marine red alga Laurencia obtusa. Planta Med. 1997, 63, 186-187. [CrossRef]

8. Sakemi, S.; Higa, T.; Jefford, C.W.; Bernardinelli, G.; Venustatriol, G. A new anti-viral triterpene tetracyclic ether from Laurencia venusta. Tetrahedron Lett. 1986, 27, 4287-4290. [CrossRef]

9. De Oliveira, A.L.L.; de Felício, R.; Debonsi, H.M. Marine natural products: Chemical and biological potential of seaweeds and their endophytic fungi. Rev. Bras. Farmacogn. 2012, 22, 906-920. [CrossRef]

10. Davyt, D.; Fernandez, R.; Suescun, L.; Mombrú, A.W.; Saldanña, J.; Dominguez, L.; Fujii, M.T.; Manta, E. Bisabolanes from the red alga Laurencia scoparia. J. Nat. Prod. 2006, 69, 1113-1116. [CrossRef]

11. Ji, N.Y.; Li, X.M.; Cui, X.M.; Wang, B.G. Two new brominated diterpenes from Laurencia decumbens. Chin. Chem. Lett. 2007, 18, 957-959. [CrossRef]

12. Iliopoulou, D.; Mihopoulos, N.; Vagias, C.; Papazafiri, P.; Roussis, V. Novel cytotoxic brominated diterpenes from the red alga Laurencia obtusa. J. Org. Chem. 2003, 68, 7667-7674. [CrossRef] [PubMed]

13. Lyakhova, E.G.; Kalinovsky, A.I.; Dmitrenok, A.S.; Kolesnikova, S.A.; Fedorov, S.N.; Vaskovsky, V.E.; Stonik, V.A. Structures and absolute stereochemistry of nipponallene and neonipponallene, new brominated allenes from the red alga Laurencia nipponica. Tetrahedron Lett. 2006, 47, 6549-6552. [CrossRef]

14. Kladi, M.; Vagias, C.; Stavri, M.; Rahman, M.M.; Gibbons, S.; Roussis, V. C15 acetogenins with antistaphylococcal activity from the red alga Laurencia glandulifera. Phytochem. Lett. 2008, 1, 31-36. [CrossRef]

15. Ojika, M.; Yoshida, Y.; Okumura, M.; Ieda, S.; Yamada, K. Aplysiadiol, a new brominated diterpene from the marine mollusk Aplysia kurodai. J. Nat. Prod. 1990, 53, 1619-1622. [CrossRef]

16. Vairappan, C.S.; Ishii, T.; Lee, T.K.; Suzuki, M.; Zhaoqi, Z. Antibacterial Activities of a New Brominated Diterpene from Borneon Laurencia spp. Mar. Drugs 2010, 8, 1743-1749. [CrossRef]

17. Waraszkiewicz, S.M.; Sun, H.H.; Erickson, K.L.; Finer, J.; Clardy, J. C15 halogenated compounds from the Hawaiian marine alga Laurencia nidifica. Maneonenes and isomaneonenes. J. Org. Chem. 1978, 43, 3194-3204. [CrossRef]

18. Ayyad, S.-E.N.; Al-Footy, K.O.; Alarif, W.M.; Sobahi, T.R.; Bassaif, S.A.; Makki, M.S.; Asiri, A.M.; Halwani, A.A.Y.; Badria, A.F.; Badria, F.A.-R. Bioactive C15 acetogenins from the red alga Laurencia obtusa. Chem. Pharm. Bull. 2011, 59, 1294-1298. [CrossRef] [PubMed]

19. Ji, N.-Y.; Li, X.-M.; Xie, H.; Ding, J.; Lia, K.; Ding, L.-P.; Wang, B.-G. Highly Oxygenated Triterpenoids from the Marine Red Alga Laurencia mariannensis (Rhodomelaceae). Helv. Chim. Acta 2008, 91, 1940-1946. [CrossRef]

20. Ji, N.-Y.; Li, X.-M.; Li, K.; Ding, L.-P.; Gloer, J.B.; Wang, B.-G. Diterpenes, Sesquiterpenes, and a C15-Acetogenin from the Marine Red Alga Laurencia Mariannensis. J. Nat. Prod. 2007, 70, 1901-1905. [CrossRef]

21. Takahashi, Y.; Suzuki, M.; Abe, T.; Masuda, M. Anhydroaplysiadiol from Laurencia japonensis. Phytochemistry 1998, 48, 987-990. [CrossRef]

22. Zhao, Y.; Yue, J.-M.; He, Y.-N.; Lin, Z.-W.; Sun, H.-D. Eleven New Eudesmane Derivatives from Laggera pterodonta. J. Nat. Prod. 1997, 60, 545-549. [CrossRef]

23. Sun, H.H.; Waraszkiewicz, S.M.; Erickson, K.L.; Finer, K.L.; Clardy, J. Dictyoxepin and Dictyolene, Two New Diterpenes from the Marine Alga Dictyota acutiloba (Phaeophyta). J. Am. Chem. Soc. 1977, 99, 3516-3517. [CrossRef] [PubMed] 
24. Bowden, B.F.; Coll, J.C.; Liyanage, N.; Mitcell, S.J.; Stokie, G.J.; Blount, J.F. Studies of Australian soft corals. VIII. A chemical and crystallographic study of a novel bicyclic diterpene alcohol with a rearranged skeleton from an unknown species of soft coral. Aust. J. Chem. 1978, 31, 2039-2047. [CrossRef]

25. Poet, S.E.; Ravi, B.N. Three new diterpenes from a soft coral Nephthea species. Aust. J. Chem. 1982, 35, 77-83. [CrossRef]

26. Goll, J.C.; Bowden, B.F.; Konig, G.M.; Braslau, R.; Price, I.R. Studies of Australian Soft Corals. The Natural Products Chemistry of Alcyonacean Soft Corals with Special Reference to the Genus Lobophytum. Bull. Soc. Chim. Belg. 1986, 95, 815.

27. Laatsch, H. AntiBase: The Natural Compound Identifier; Wiley-VCH Verlag: Weinheim, Germany, 2017.

28. Vairappan, C.S.; Suzuki, M.; Abe, T.; Masuda, M. Halogenated metabolites with antibacterial activity from the Okinawan Laurencia species. Phytochemistry 2001, 58, 517-523. [CrossRef]

29. Lindel, T.; Junker, J.; Koeck, M. 2D-NMR-guided constitutional analysis of organic compounds employing the computer program COCON. Eur. J. Org. Chem. 1999, 1999, 573-577. [CrossRef]

30. Nasr, A.H. The Marine Algae of Alexandria. 1-A Report on Some Marine Algae Collected from the Vicinity of Alexandria; Notes and Memoirs No. 36; Government Press: Bulaq, Cairo, 1940; p. 33.

31. Abou-El Wafa, G.S.E.; El-Naggar, M.E.E. Studies on the Biological Activities of Some Species of Egyptian Marine Algae, Private Communication; Mansoura University: El-Mansoura, Egypt, 2005.

32. Burkholder, P.R.; Burkholder, L.M.; Almodovar, L.R. Antibiotic activity of some marine algae of Puerto Rico. Bot. Mar. 1960, 2, 149-156. [CrossRef]

33. Sajid, I.; Fondja, Y.C.B.; Shaaban, K.A.; Hasnain, S.; Laatsch, H. Antifungal and antibacterial activities of indigenous Streptomyces isolates from saline farmlands: Prescreening, ribotyping and metabolic diversity. World J. Microbiol. Biotechnol. 2009, 25, 601-610. [CrossRef]

34. Shaaban, K.A.; Shaaban, M.; Rahman, H.; Grün-Wollny, I.; Laatsch, H. Karamomycins, A.-C: Novel 2-Naphthalen-2-yl-thiazoles from Nonomuraea endophytica sp. J. Nat. Prod. 2019, 82, 870-877. [CrossRef] [PubMed] 